TRANSPORT

\title{
RESEARCH INTO THE QUALITY OF FUELS AND THEIR BIOCOMPONENTS
}

\author{
Jonas Matijošius ${ }^{1}$, Edgar Sokolovskij ${ }^{2}$ \\ Dept of Automobile Transport, Vilnius Gediminas Technical University, \\ J. Basanavičiaus g. 28, 03224 Vilnius, Lithuania \\ E-mails: ${ }^{1}$ jonas.matijosius@ti.vgtu.lt; ${ }^{2}$ edgar.sokolovskij@ti.vgtu.lt
}

Received 14 October 2008; accepted 3 September 2009

\begin{abstract}
The article provides a closer look into the quality properties of fuels, analyses the merits and demerits of using biocomponents in petrol and diesel and overviews the ways of improving the quality of fuels. Work carried out by the authors covers the determination of the basic quality properties (density, kinematic viscosity and flash point) of petrol, diesel, methanol, ethanol, buthanol as well as rape methyl and rape ethyl esters. The paper investigates how these qualities influence the operational performance of the engine and puts forward the age-dependence analysis of diesel quality properties.
\end{abstract}

Keywords: fuels, petrol, diesel, biocomponents, biofuel, quality of fuels.

\section{Introduction}

In the context of increasing requirements for fuels, including requirements related to their environmental impact, the issue of the quality of fuels is gaining more and more importance. The quality of fuels is also subject to compliance with standards the level of which is being enhanced on an ongoing basis. In addition, fuels produced and marketed in Lithuania shall conform to the standards adopted in the European Union placing much more stringent requirements than the national standards that existed prior to the country's accession to the EU (Pukalskas 2002).

Particular consideration in updating the standards of quality is given to the environmental performance of fuels including such properties as the content of sulphur, polycyclic aromatic hydrocarbons and other contaminants found in diesel and petrol. Along with the parameters of the examined fuels, fuel performance characteristics are significantly influenced by the number of cetane, lower calorific value and evaporation characteristics. With a view to ensuring the conformity of fuels to new requirements, it is necessary to undertake a technological upgrade of oil refineries, namely to modernize the equipment of petrol chemical processing, to install or upgrade desulphuring equipment etc (Lingaitis and Pukalskas 2008; Butkus et al. 2007).

Research into the quality of fuels and their biocomponents also presented by another researchers, for example: Baltènas et al. (1998); Pukalskas (2002); Jeuland et al. (2004); Li et al. (2005); Makarevičienè et al. (2005); Thir- ouard and Cherel (2006); Agarwal (2007); Albrecht et al. (2007); Arsie et al. (2007); Butkus et al. (2007); He et al. (2003); Lebedevas et al. (2007a and 2007b); Raslavičius and Markšaitis (2007); Al-Hasan and Al-Momany (2008); Boychenko et al. (2008); Lingaitis and Pukalskas (2008); Lebedevas and Lebedeva (2009); Raslavičius (2009); Török (2009); Petrović et al. (2009) and others.

\section{Quality Properties of Fuels}

The quality of fuels is one of the key factors having an impact upon the operational performance of the engine. It is defined in terms of a range of quality properties. The quality of petrol and diesel is measured by about 20 different properties, the specific values and norms whereof are indicated in the respective Quality Certificates issued for each particular type of fuel. Ordinary users may find it difficult to make sense of these sophisticated requirements while the impact of poor quality fuel on the technical condition of a vehicle does not emerge immediately and becomes apparent only at a later stage. For this reason, some users tend to make their choice on cheaper fuels of questionable quality. However, the price of products is generally determined by their quality as the process of producing quality fuels requires the employment of the most advanced and hence rather costly technologies. It is true that cheaper fuels intended for use within the eastern (non-EU) market are generally manufactured on less sophisticated and thus cheaper technologies and using cheaper fuel additives. There- 
fore, the properties of such fuels and subsequently their quality can hardly live up to the requirements prescribed under the standards applicable in the European Union.

The major properties of quality and their normative values for the most widely used petrol with Octane Number 95 and diesel fuel are presented in Tables 1 and 2 respectively.

Table 1. Quality properties of the most widely used petrol with Octane Number 95 and their normative values

(LST EN 228:2004)

\begin{tabular}{|c|c|}
\hline $\begin{array}{l}\text { Unleaded petrol grade } 95 \text { class with } \\
\text { bio-ETBE (max } 50 \text { ppm) }\end{array}$ & Norm \\
\hline Research octane number, RON, min. & 95 \\
\hline Motor octane number, MON, min. & 85 \\
\hline Lead content, mg/l, max. & 5 \\
\hline Density at $15^{\circ} \mathrm{C}, \mathrm{kg} / \mathrm{m}^{3}$ & $720-775$ \\
\hline Sulfur content, mg/kg, max. & 50 \\
\hline Oxidation stability, minutes, $\min$ & 360 \\
\hline $\begin{array}{l}\text { Existent gum content (solvent washed), } \\
\mathrm{mg} / 100 \mathrm{ml} \text {, max. }\end{array}$ & 5 \\
\hline $\begin{array}{l}\text { Copper strip corrosion }\left(3 \mathrm{~h} \text { at } 50^{\circ} \mathrm{C}\right) \text {, } \\
\text { rating, max. }\end{array}$ & 1 \\
\hline Appearance & Clear and bright \\
\hline \multicolumn{2}{|l|}{ Hydrocarbon type content, \% (v/v) max: } \\
\hline Olefins & 18 \\
\hline Aromatics & 35 \\
\hline Benzene content, \% (v/v), max. & 1 \\
\hline Oxygen content, $\%(\mathrm{v} / \mathrm{v}), \max$ & 2.7 \\
\hline \multicolumn{2}{|l|}{ Oxygenates content, $\%(\mathrm{v} / \mathrm{v})$, max.: } \\
\hline Methanol & 3 \\
\hline Ethanol & 5 \\
\hline Isopropyl alcohol & 10 \\
\hline Isobutyl alcohol & 10 \\
\hline Tret-butyl alcohol & 7 \\
\hline Ethers (5 or more C- atoms) & 15 \\
\hline MTBE & Report \\
\hline ETBE & Report \\
\hline MTAE(TAME) & Report \\
\hline Other oxygenates & 10 \\
\hline Vapour pressure, (VP0, $\mathrm{kPa}$ & $50-80$ \\
\hline \multicolumn{2}{|l|}{ Distillation: } \\
\hline Evaporated at $70^{\circ} \mathrm{C}(\mathrm{E} 70), \%(\mathrm{v} / \mathrm{v})$ & $22-50$ \\
\hline Evaporated at $100^{\circ} \mathrm{C}(\mathrm{E} 100), \%(\mathrm{v} / \mathrm{v})$ & $46-71$ \\
\hline Evaporated at $150^{\circ} \mathrm{C}(\mathrm{E} 150), \%(\mathrm{v} / \mathrm{v}), \mathrm{min}$. & 75 \\
\hline Final boiling point(FBP), ${ }^{\circ} \mathrm{C}, \max$ & 210 \\
\hline Distillation residue, $\%(\mathrm{v} / \mathrm{v})$, max. & 2 \\
\hline Vapour Lock Index, VLI, max. & 1050 \\
\hline Bio - ETBE content, \% (v/v) & 7.74 \\
\hline $\begin{array}{l}\text { Bio-ETBE content, that is calculated as } \\
\text { bioethanol, } \%(\mathrm{v} / \mathrm{v})\end{array}$ & Calculate \\
\hline Bioethanol content, $\%(\mathrm{~m} / \mathrm{m})$ & Calculate \\
\hline
\end{tabular}

Table 2. Quality properties of diesel and their normative values (LST EN 590:2004)

\begin{tabular}{|c|c|}
\hline $\begin{array}{l}\text { Diesel grade E with FAME (max. } 50 \\
\text { ppm S) }\end{array}$ & Norm \\
\hline Cetane number, min & 51 \\
\hline Cetane index, min & 46 \\
\hline Density at $15^{\circ} \mathrm{C}, \mathrm{kg} / \mathrm{m}^{3}$ & $820-845$ \\
\hline $\begin{array}{l}\text { Polycycling aromatic hydrocarbons, } \\
\%(\mathrm{~m} / \mathrm{m}), \max .\end{array}$ & 11 \\
\hline Sulfur content, mg/kg, max. & 50 \\
\hline Flash point, ${ }^{\circ} \mathrm{C}$ & 55 \\
\hline $\begin{array}{l}\text { Carbon residue (on } 10 \% \text { distilation } \\
\text { residue), } \% \mathrm{~m} / \mathrm{m} \text {, max. }\end{array}$ & 0.3 \\
\hline Ash content, $\% \mathrm{~m} / \mathrm{m}, \max$. & 0.01 \\
\hline Water content, mg/kg, max. & 200 \\
\hline Total contamination, mg/kg, max. & 24 \\
\hline $\begin{array}{l}\text { Copper strip corrosion }\left(3 \mathrm{~h} \text { at } 50^{\circ} \mathrm{C}\right) \text {, } \\
\text { rating, max. }\end{array}$ & 1 \\
\hline Oxidation stability, $\mathrm{g} / \mathrm{m}^{3}$, max. & 25 \\
\hline $\begin{array}{l}\text { Lubricity, corrected wear scar diameter } \\
\text { (wsd 1.4) at } 60^{\circ} \mathrm{C}, \mu \mathrm{m}, \max .\end{array}$ & 460 \\
\hline Viscosity, at $40^{\circ} \mathrm{C}, \mathrm{mm}^{2} / \mathrm{s}$ & $2-4.5$ \\
\hline \multicolumn{2}{|l|}{ Distillation: } \\
\hline$\%(\mathrm{v} / \mathrm{v})$ recovered at $250^{\circ} \mathrm{C}, \max ^{\prime \prime}$ & 65 \\
\hline$\%(\mathrm{v} / \mathrm{v})$ recovered at $350^{\circ} \mathrm{C}$, $\mathrm{min}$. & 85 \\
\hline $95 \%\left(\mathrm{v} / \mathrm{v}\right.$ recovered, at ${ }^{\circ} \mathrm{C}$, $\max$. & 360 \\
\hline $\mathrm{CFPP},{ }^{\circ} \mathrm{C}, \max$ & -15 \\
\hline Alkyl nitrate content, \% (v/v) & Report \\
\hline Cloud point, ${ }^{\circ} \mathrm{C}$ & Report \\
\hline FAME content, \% (v/v) & 5 \\
\hline Fame content, \% (m/m) & Calculate \\
\hline
\end{tabular}

The properties of fuels may be split into several groups: the first one is represented by operational properties such as fuel octane number or properties determining the durability and chemical stability or the chemical composition of fuels, the second group includes properties related to the safety of fuels within transportation and storage such as flash point and the third one, which appears to be the largest, covers properties related to environmental requirements such as sulphur content. The current focus with a view to establishing more stringent requirements is placed exclusively on the environment-related properties of fuels. For instance, tighter norms now are being set to the content of sulphur as the combustion of sulphur compounds causes certain environmental problems when in the result of photochemical reactions, a certain acid medium is formed, due to which, rain becomes unusually acid. Such rain in turn increases the content of acid in soil. Norms for operational properties, however, are being updated to a much lesser extent. 


\section{Ways of Improving the Quality of Fuels}

Under the existing EU standards, petrol and diesel shall contain biocomponents in the total fuel balance; moreover, it is required that the content of such biocomponents shall be continuously increased. Enlarging the concentration of biocomponents in used fuel blends, in turn, initiate the provided attractiveness of biofuel blends. The use of alternative fuels or their components is also promoted. Alternative fuels are defined as any materials or substances produced from renewable sources that can substitute petroleum fuels or any part thereof and are used for the purposes of economy and with a view to reducing pollution caused by transport. The fuels of vegetal origin mixed with conventional fuels or added thereto as individual components are most frequently used as a type of alternative fuels (Jeuland et al. 2004).

Control over combustion quality and improvement in the antiknock properties of petrol engines through the use of oxygenates has become widely accepted practise. Oxygenates are chemical compounds with molecules containing oxygen. The presence of such compounds in petrol improves the process of combustion in terms of its outcome, i.e. hydrocarbons get burned up to a greater degree leaving less unburnt hydrocarbon and carbon monoxide in exhaust fumes. $\mathrm{NO}_{\mathrm{x}}, \mathrm{CO}_{\mathrm{x}}$ and particle matter level burn higher if compared with mineral diesel. This is explained by higher combustion temperatures, higher excess air ratio and a higher amount of oxygen biofuels (Arsie et al. 2007; Albrecht et al. 2007). Furthermore, such oxygen compounds increase the octane number of petrol. Methyl tert-butyl ether (MTBE) and ethyl tert-butyl ether (ETBE) are among the most widely used oxygen compounds. Now, oxygenates are used as an individual component of petrol. In addition to ethers, methanol and ethanol may be also used as the source of oxygen and a high octane number. Their content constitutes up to $15-25 \%$ of the total chemical structure of petrol fuel. However, at low temperatures, these alcohols tend to segregate in petrol; moreover, they facilitate the absorption of moisture in petrol, hence increasing the risk of corrosion. In the future, the role of ethers and alcohols is only likely to increase as they may be derived from the raw materials of biological origin, i.e. from renewable sources. For instance, grains may be used for the primary extraction of bioethanol and the subsequent production of ethyl tert-butyl ether (ETBE).

In diesel engines, most commonly used biocomponents are vegetable oils such as rape-oil or oil esters, rape methyl ester (RME) and rape ethyl ester (REE) of which are the most popular. Like in the case with petrol fuel, the content of such biocomponents constitutes up to $15-25 \%$ of the total chemical structure of fuel. The cetane number of esters (e.g., 51-65 for RME) is similar to that of diesel fuels, and though their consumption is somewhat higher, the quality of the fuel combustion process is improved. However, at low temperatures, the performance of esters tends to go down, and therefore it is recommended that their content in diesel petrol in winter season shall be decreased (Baltenas et al. 1998).

Both petrol and diesel engines may run exclusively on alternative fuels, however, in such case, the construction of the engine should be modified. Unfortunately, such modifications in the majority of vehicles do not appear to be feasible, and therefore efforts are made to ensure that the operational properties of biological fuels should be similar to those of conventional fuels. This may be achieved by the way of adding a small amount of biocomponents into conventional fuels (Thirouard and Cherel 2006).

Today, the properties of petrol are generally enhanced through improving the chemical structure of petrol, upgrading production technologies and adding the required amount of oxygenates (MTBE, ETBE, etc.), the octane number whereof, as determined by the method of testing, makes up 118.

The quality of petrol combustion may be improved through the use of different additives, for instance, organic manganese compounds the oxide of which is formed during the combustion process and contaminates spark plugs. Fortunately, the new alternative methods of improving the antiknock properties of petrol are now available and include the application of up-to-date technologies and chemical processing techniques in the production of petrol and the use of high octane number components (oxygenates).

As has been mentioned before, the major focus with a view to tightening quality requirements is shifted on the environment-related properties of fuels. Thus, the content of sulphur and other contaminants present in diesel and petrol is being reduced. Though the content of sulphur in petrol distillates is considerably lower than that in diesel and this issue in the past lacked proper address, in response to ever-growing environmental requirements for petrol in Europe and hence in Lithuania, there has been launched the production of sulphur-free petrol, i.e. petrol with reduced content of sulphur. This type of petrol is special in that sense that it helps to solve environmental problems related to atmospheric pollution by sulphur compounds. Sulphur-free petrol refers to petrol, wherein the content of sulphur is less than $10 \mathrm{ppm}(10 \mathrm{mg} / \mathrm{kg})$.

Over the last decade, the content of sulphur compounds in petrol fuels produced in Lithuania $(\mathrm{AB}$ Mažeikiu nafta) decreased by 100 times (from $0.1 \%$ down to $0.001 \%$ ), whereas in diesel fuels, this decrease was as high as 200 times (from $0.2 \%$ down to $0.001 \%$ ). Previously, the fuels, wherein the amount of sulphur compounds was small, used to be referred to as lowsulphur content fuels. Later, after imposing more stringent environmental requirements in the European Union, petrol with sulphur content less than $10 \mathrm{ppm}$ (10 $\mathrm{mg} / \mathrm{kg}$ ) was renamed to sulphur-free petrol. However, 'sulpher-free' is only an arbitrary term that does not imply that sulphur is absolutely absent in petrol but rather indicates that the content of sulphur compounds is very low (below $10 \mathrm{mg} / \mathrm{kg}$ ). 


\section{Testing the Quality of Fuels}

For the purpose of evaluating differences between the quality properties of different fuels and their components and determining their effect on the indicators of fuel quality, the measurements of fuel density, kinematic viscosity and flash point were performed. Density, kinematic viscosity and flash point were measured using an areometer, a capillary viscometer and a closed cup tester respectively. These properties were measured for both petrol and diesel as well as for other fuels and their components including methanol, ethanol, buthanol, rape methyl ester and rape ethyl ester. The results of these tests are presented in Table 3.

Table. 3. Results of testing the quality properties of fuels and their components

\begin{tabular}{lccc}
\hline $\begin{array}{c}\text { Fuels and their } \\
\text { components }\end{array}$ & $\begin{array}{c}\text { Density at } \\
20^{\circ} \mathrm{C}, \mathrm{kg} / \mathrm{m}^{3}\end{array}$ & $\begin{array}{c}\text { Kinematic } \\
\text { Viscosity, } \\
\text { at } 40^{\circ} \mathrm{C}, \\
\mathrm{m}^{2} / \mathrm{s} \times 10^{-6}\end{array}$ & $\begin{array}{c}\text { Flash } \\
\text { point } \\
\mathrm{C}^{\circ}\end{array}$ \\
\hline Petrol (95 class) & 746.6 & 0.631 & -40 \\
\hline Diesel & 844.6 & 2.54 & 65 \\
\hline Methanol $\left[\mathrm{CH}_{3} \mathrm{OH}\right]$ & 792 & 0.62 & 8 \\
\hline Ethanol $\left[\mathrm{C}_{2} \mathrm{H}_{5} \mathrm{OH}\right]$ & 789 & 1.16 & 13 \\
\hline Buthanol $\left[\mathrm{C}_{4} \mathrm{H}_{9} \mathrm{OH}\right]$ & 812 & 3.62 & 26 \\
\hline Rape methyl ester & 890 & 4.31 & 110 \\
\hline Rape ethyl ester & 890.4 & 4.86 & 112 \\
\hline
\end{tabular}

As can be seen from the values of the quality properties of fuels and their components presented in Table 3, using such alcoholic fuels as methanol and ethanol in petrol engines increases the density, viscosity and flash point of fuel. An increase in density and viscosity lowers the quality of fuel spray and filtering properties. On the other hand, the safety of such fuels at storage is enhanced as the value of flash point in this case is higher. The major demerit of spiritual fuels and their components lies in their tendency to segregate in petrol at low temperatures; moreover, they facilitate the absorption of moisture in petrol hence increasing the risk of corrosion.

Tests on the second-generation fuels, namely buthanol which may be used as a substitute of methanol and ethanol in the future, are already underway. The octane number of buthanol is about 95, i.e. similar to that of the most popular petrol with Octane Number 95 and it mixes in petrol more easily. The measured values of buthanol density, kinematic viscosity and flash point are presented in Table 3 above. These values of buthanol appear to be even higher than the respective values of methanol and ethanol, and therefore its effect on the quality of fuels is similar.

The use of biocomponents (oils and esters) in diesel engines worsens fuel spray and filtering properties which happens due to higher density and viscosity values. On the other hand, a higher flash point of these fuels enhances their safety at storage.

In addition, analysis aimed at identifying the dependence of diesel quality properties (density, viscosity and flash point) upon the date of fuel manufacture was performed. This age-dependence analysis was based on the comparison of diesel fuel produced in 2004 with the samples of diesel of the most recent manufacture date. The findings of the carried out analysis are presented in Fig. 1.

Additionally, fuel can be used to determine the quality of the twelfth and thirteenth carbon isotopic ratio. Carbon isotopic ratio is measured using a stable isotope mass spectrometer Thermo Finnigan Delta plus Advantage and the input device - an ultra gas chromatograph Finnigan Trace GC. Figure 2 shows that in the before used fuels, it will be lower due to the ongoing process of oxidation, and thus more light fractions will be evaporated, which will worsen engine's combustibility.

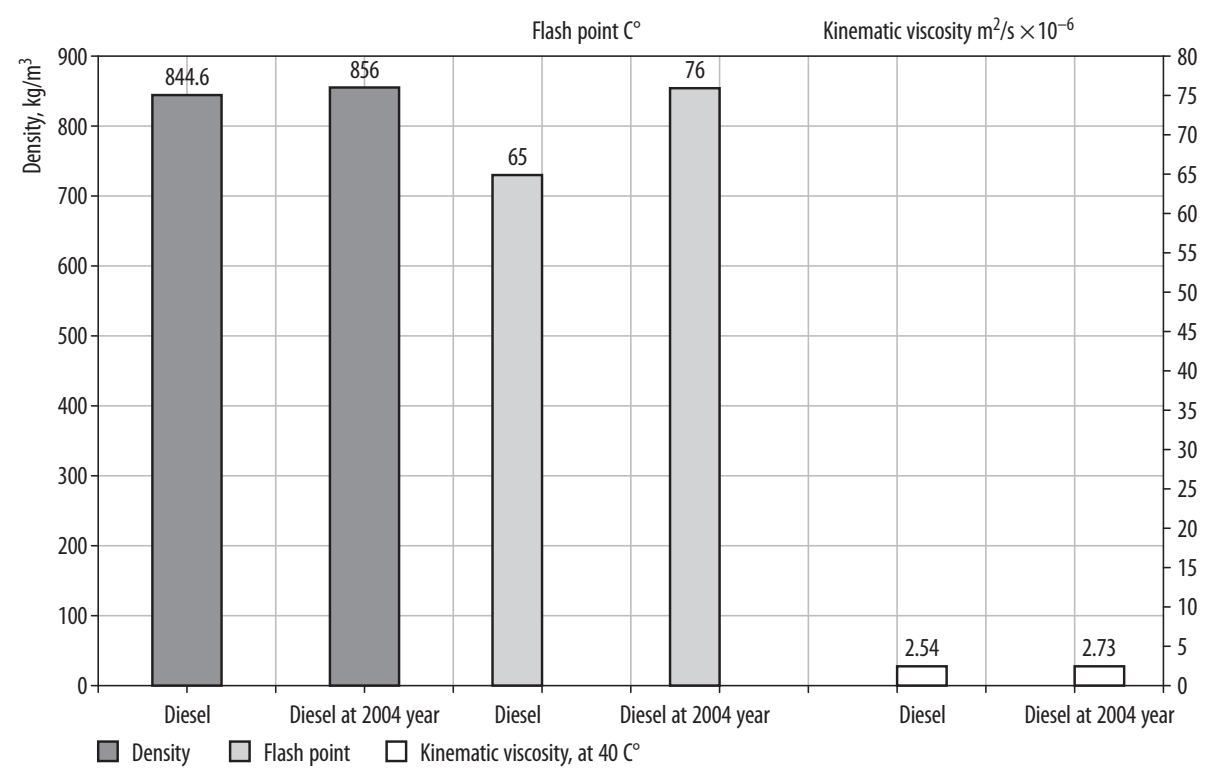

Fig. 1. Results of the age-dependence analysis of diesel quality properties 


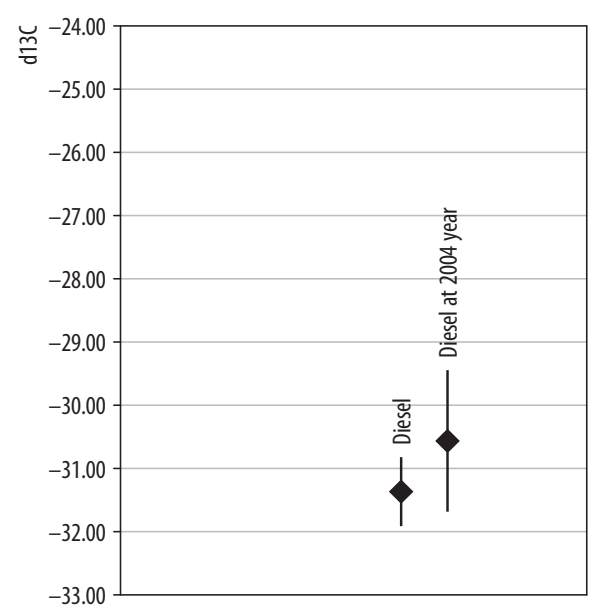

Fig. 2. Results of the age-dependence analysis of the diesel quality properties of the twelfth and thirteenth carbon isotopic ratio

\section{Conclusions}

1. The recent focus with a view to establishing more stringent requirements is mainly placed on the environment-related properties of fuels such as the content of sulphur, polycyclic aromatic hydrocarbons and other contaminants found in diesel and petrol. For this reason and in particular with a view to the need for liming the consumption of oil-based raw materials in the production of fuels, the use of biocomponents in fuels is gaining an increasingly wider scale. Moreover, as prescribed by the requirements existing in the European Union, the content of these biocomponents in fuels is continuously increasing.

2. The samples of petrol, diesel, methanol, ethanol, buthanol as well as rape methyl and rape ethyl esters were tested for determining the properties of density, kinematic viscosity and flash point in these substances. The values of the measured properties are presented in Table 3. Based on the results of the comparison of quality properties possessed by fuels and their components, the use of biocomponents in engines such as alcoholic fuels, oils or esters increases the value of fuel density, viscosity and flash point which in turn has a deteriorating effect on the quality of fuel spray and filtering properties. On the other hand, it enhances the safety of such fuels at storage.

3. The age-dependence analysis of diesel quality properties (density, kinematics viscosity and flash point) show that the values of density, viscosity and flash point in the samples of diesel produced in 2004 as compared to those of the most recent manufacture date, appear to be higher by $1.4 \%, 7.4 \%$ and $17 \%$ respectively (Fig. 2). The use of such diesel worsens the quality of combustible mixture and contaminates the combustion chamber of engine run on such diesel with more burn scale and other products of incomplete combustion.

\section{References}

Agarwal, A. K. 2007. Biofuels (alcohols and biodiesel) applications as fuels for internal combustion engines, Progress in Energy and Combustion Science 33(3): 233-271. doi:10.1016/j.pecs.2006.08.003.

Albrecht, A.; Grondin, O.; Le Berr, F.; Le Solliec, G. 2007. Towards a stronger simulation support for engine control design: a methodological point of view, Oil \& Gas Science and Technology - Rev. IFP 62(4): 437-456.

Al-Hasan, M. I.; Al-Momany, M. 2008. The effect of iso-butanol-diesel blends on engine performance, Transport 23(4): 306-310. doi:10.3846/1648-4142.2008.23.306-310.

Arsie, I.; Pianese, C.; Sorrentino, M. 2007. Effects of control parameters on performance and emissions of HSDI diesel engines: investigation via two zone modeling, Oil \& Gas Science and Technology - Rev. IFP 62(4): 457-469.

Baltenas, R. ; Sologubas, L. ; Sologubas, R. 1998. Automobiliu degalai ir tepalai [Automobile Fuels and Lubricants]. Vilnius, TEV, $416 \mathrm{p}$.

Boychenko, S.; Shkilnuk, I.; Turchak, V. 2008. The problems of biopollution with jet fuels and the way of achieving solution, Transport 23(3): 253-257. doi:10.3846/1648-4142.2008.23.253-257.

Butkus, A.; Pukalskas, S.; Bogdanovičius, Z. 2007. The influence of turpentine additive on the ecological parameters of diesel engines, Transport 22(2): 80-82.

He, B.-Q.; Shuai, S.-J.; Wang J.-X.; He, H. 2003. The effect of ethanol blended diesel fuels on emissions from a diesel engine, Atmospheric Environment 37(35): 4965-4971. doi:10.1016/j.atmosenv.2003.08.029.

Jeuland, N.; Montagne, X.; Gautrot, X. 2004. Potentiality of ethanol as a fuel for dedicated engine, Oil \& Gas Science and Technology - Rev. IFP 59(6): 559-570.

Lebedevas, S.; Lebedeva, G. 2009. The problems of using alcohol biofuel mixtures in the Lithuanian transport system, Transport 24(1): 58-65. doi:10.3846/1648-4142.2009.24.58-65.

Lebedevas, S.; Vaicekauskas, A.; Suškov, P. 2007a. Presumptions of effective operation of diesel engines running on rme biodiesel. Research on kinetics of combustion of RME biodiesel, Transport 22(2): 126-133.

Lebedevas, S.; Vaicekauskas, A.; Lebedeva, G.; Makarevičienè, V.; Janulis, P. 2007b. Change in operational characteristics of diesel engines running on RME biodiesel fuel, Energy \& Fuels 21(5): 3010-3016. doi:10.1021/ef060314t.

Li, D.-G.; Zhen, H.; Xingcai, L.; Wu-Gao, Z.; Jian-Guang, Y. 2005. Physico-chemical properties of ethanol-diesel blend fuel and its effect on performance and emissions of diesel engines, Renewable Energy 30(6): 967-976. doi:10.1016/j.renene.2004.07.010

Lingaitis, L. P.; Pukalskas, S. 2008. Ecological aspects of using biological diesel oil in railway transport, Transport 23(2): 138-143. doi:10.3846/1648-4142.2008.23.138-143.

Makarevičienè, V.; Sendžikienè, E.; Janulis, P. 2005. Solubility in multi-component biodiesel fuel systems, Bioresource Technology 96(5): 611-616. doi:10.1016/j.biortech.2004.06.007.

Petrović, J.; Ivković, I.; Vujačić, I.; Žeželj, S. 2009. Possibilities of buses on alternative fuel in public urban transport in Belgrade, Technological and Economic Development of Economy 15(1): 78-89. doi: 10.3846/1392-8619.2009.15.78-89. 
Pukalskas, S. 2002. Etilo spirito ịtaka dyzelinio variklio ekonomiškumui ir dūmuotumui: daktaro disertacija, technologijos mokslai, transporto inžinerija [The Influence of Ethyl Alcohol on Economy and Smoke of a Disel Engine: Doctoral Dissertation, technological sciences, Transport Engineering]. Vilnius: VGTU. 152 p. (in Lithuanian).

Raslavičius, L. 2009. Research into three-component combustible mixture application for fuelling diesel engines. Summary of Doctoral Dissertation (Technological Sciences, Transport Engineering). Kaunas: Technologija. $32 \mathrm{p}$.

Raslavičius, L.; Markšaitis, D. 2007. Research into three-component biodiesel fuels combustion process using a single droplet technique, Transport 22(4): 312-315.

Thirouard, B.; Cherel, J. 2006. Nature of CAI combustion and air/fuel ratio stratification effects, Oil \& Gas Science and Technology - Rev. IFP 61(1): 95-119.

Török, Á. 2009. Theoretical estimation of the environmental impact of biofuel mixtures, Transport 24(1): 26-29. doi:10.3846/1648-4142.2009.24.26-29. 